\title{
Maximizing Student Potential Versus Building Community: An Exploration of Right-Wing Authoritarianism, Social Dominance Orientation, and Preferred Practice Among Supporters of Gifted Education
}

Jennifer Riedl Cross

College of William and Mary, jrcross@wm.edu

Tracy L. Cross

College of William and Mary, tlcross@wm.edu

Holmes Finch

Follow this and additional works at: https://scholarworks.wm.edu/educationpubs

Part of the Gifted Education Commons

\section{Recommended Citation}

Cross, Jennifer Riedl; Cross, Tracy L.; and Finch, Holmes, Maximizing Student Potential Versus Building Community: An Exploration of Right-Wing Authoritarianism, Social Dominance Orientation, and Preferred Practice Among Supporters of Gifted Education (2010). Roeper Review, 32(4), 235-248.

https://doi.org/10.1080/02783193.2010.508155 
Maximizing Student Potential Versus Building Community: An Exploration of RightWing Authoritarianism, Social Dominance Orientation, and Preferred Practice Among Supporters of Gifted Education

Jennifer Riedl Cross

Tracy L. Cross

W. Holmes Finch

Ball State University

Muncie, IN 47306

\section{Final version accepted for publication}

Cross, J.R., Cross, T. L., \& Finch, W. H. (2010). Maximizing student potential versus building community: An exploration of right-wing authoritarianism, social dominance orientation, and preferred practice among supporters of gifted education. Roeper Review, 32, 235-248. 


\begin{abstract}
Social dominance orientation (SDO), right-wing authoritarianism (RWA), and socially desirable responding were examined among a sample of self-identified supporters of gifted education $(N=341), 70 \%$ of whom had an official role in gifted education as researchers, teachers, or G/T trainers. The sample was primarily female, White, welleducated and upper middle class. The relationship of SDO, RWA, socially desirable responding and support for various gifted education practices such as testing for identification, curricular differentiation in a heterogeneous classroom, and cooperative learning was explored through latent class analysis and logistic regression. Two distinct groups, Communitarians and Individualists, were found on the basis of their support for different gifted programming. Higher deference to authority among Communitarians predicted support for an inclusive social norm, compared to a preference for maximizing potential without regard for inclusion among the Individualists, who were less likely to defer to authority.
\end{abstract}




\section{Maximizing Student Potential Versus Building Community: An Exploration of}

\section{Right-Wing Authoritarianism, Social Dominance Orientation, and Preferred}

\section{Practice Among Supporters of Gifted Education}

In the field of gifted education, researchers have spent decades studying gifted children and how to best serve them, but little attention has been paid to the individuals who support efforts to provide services to gifted students. Studies of attitudes towards gifted children are generally aimed at teachers (Cramond \& Martin, 1987; Gagné, 1983; McCoach \& Siegle, 2007; Morris, 1987) or the students themselves (Cross, al Lawati, Frazier, \& Cross, 2007; Tannenbaum, 1962). Rarely is the spotlight turned on those who are already dedicated to supporting services for the gifted. Critical theorists examine the role of education in society (e.g., Apple, 1990; Giroux, 2005) and challenge educators and policymakers to explore the contextual reasons for support of different educational methods. A historical perspective on the ideological foundation of our educational system suggests that it has long served as an important "instrument of social control" (Apple, 1990, p. 72). As supporters of gifted education may appear to present a homogeneous group, our educational system is strengthened by analysis and critiques of their support. Cross and Cross (2005) proposed that there are deep psychological underpinnings that provide different motivations to support gifted education. This study combines research from gifted education and cognitive and social psychology to answer questions about the reasons behind support for different educational practices.

\section{Gifted Education and Prejudice}

As research in the field of gifted education has evolved, the truly different needs of students with gifts and talents have become more apparent. When schools attempt to 
work towards an appropriate education for their gifted students, however, they may be criticized for elitist practices (e.g., Oakes, 1985; Sapon-Shevin, 1994). In fact there are ways in which gifted education practice can be discriminatory - "treating people differently from others based primarily on membership in a social group" (Whitley \& Kite, 2006, p. 8). For example, when identification practices select nearly all White, upper-middle income students, students of color or low SES with similar potential are being discriminated against. When no opportunity for an appropriate education exists in a community that does not support gifted education, all children with exceptional ability are unable to realize their potential. Without the necessary resources, these underserved students will be unlikely to achieve the test scores required to gain access to colleges that would otherwise have been an option for them. Unless a child's potential is spotted early and nurtured, he or she may develop other, perhaps unconstructive, ways of dealing with their unchallenging curriculum (Coleman \& Cross, 1988). The probability of identification will go down as a child's intellect receives no stimulation, particularly in comparison with a child of similar ability who is receiving an appropriate education. When such a situation repeatedly affects children in the same segments of the population, discrimination is occurring.

Some communities have chosen to eliminate their gifted programs to avoid the perceived unfairness to students without exceptional intellectual abilities. Baker and Richards (1998) found in their study of such efforts in Northeastern states that eliminating gifted programming spurred the creation of expensive, fee-based private programs for wealthy gifted children. As the wealthy children in the community received an appropriate intellectual challenge, their equally able but economically disadvantaged 
peers in the public schools would not have been similarly stimulated. The development of potential in these two populations rested on their ability to pay. Had the public schools required the maximization of potential for all students, rather than a minimum competency, gifted programming would not have been perceived as unfair.

The impetus for this study was the recognition of parallels between the potential discrimination brought about by support for gifted education that does not provide equal access for all students and contemporary theories of prejudice. Sidanius and Pratto's (1999) social dominance theory proposes that societies remain stable only when members of dominant and subordinate groups are in agreement that the dominant group is deserving of its disproportionately large share of positive social value, "all those material and symbolic things for which people strive" (Sidanius \& Pratto, p. 31). At the individual level, agreement with the dominance of one group is reflected in a person's social dominance orientation, their preference for relationships between groups in society to be hierarchical or egalitarian. One question of this study was whether supporters of gifted education would differ in this preference. Measures of Sidanius and Pratto's social dominance orientation and Altemeyer's (1981) right-wing authoritarianism are frequently paired in research on prejudice because of their complementary explanations of discriminatory behavior. This study sought to explore the relationship between these psychological constructs and support for gifted education.

\section{Social Dominance Orientation}

Whereas research on the psychology of prejudice typically emphasizes negative attitudes directed towards members of a specific group (Whitley \& Kite, 2006), social dominance theory (Sidanius \& Pratto, 1999) considers a more general picture of 
intergroup prejudices. A social group may be made up of people who differ on any salient characteristic: income level, weight, city of residence, IQ score - any possible identifiable characteristic. Social dominance orientation (SDO), an integral aspect of Sidanius and Pratto's social dominance theory, describes an individual's preference for hierarchical relationships between groups in society. Some individuals - those who score high on a measure of SDO - prefer groups to exist in a steep hierarchy, with members of one group enjoying far greater advantages in society than members of other groups. These individuals view members of the dominant group as deserving of their higher position in the social hierarchy. Individuals who score low on the SDO scale are more likely to support greater equality. Studies of SDO levels among those in various occupations have found that levels of SDO are higher among those who work in hierarchy-enhancing professions that exist primarily for the protection or benefit of the dominant group such as law, politics, or business, than among those in hierarchyattenuating professions such as social work or counseling (Pratto, Sidanius, Stallworth, \& Malle, 1994).

SDO is not a measure of interpersonal dominance. Pratto et al. (1994) found no or extremely low correlations between SDO and scores on the Dominance scales of the California Personality Inventory and the Jackson Personality Research Form. SDO is a measure of attitudes about intergroup relations, not interpersonal relations. SDO has been found to correlate positively with such attitudes as belief in sexism, conservatism, opposition to social programs, women's rights, and racial policies, and with support for military programs (Pratto et al.); with anti-Black and homosexual prejudice (Whitley, 1999); with pro-ingroup and anti-minority attitudes (Duckitt, 2001); and with generalized 
prejudice (Ekehammar, Akrami, Gylje, \& Zakrisson, 2004). SDO differs from other measures of prejudice in its focus on the individual's support for group inequality rather than on an individual's negative attitudes about the target group and support for discrimination. Discrimination that results from SDO is caused by a desire to maintain inequality between dominant and subordinate groups without an emphasis on characteristics related to specific groups.

\section{Right-Wing Authoritarianism}

Extending the research of Adorno and his colleagues (Adorno, FrenkelBrunswick, Levinson, \& Sanford, 1950) into the psychological foundation for prejudice following the atrocities of World War II, Altemeyer $(1981,1998)$ proposed right-wing authoritarianism (RWA); a constellation of attitudes that has been repeatedly associated with various forms of prejudice (e.g., against feminists [Duncan, Peterson, \& Winter, 1997], homosexuals [Whitley \& Lee, 2000], and immigrants [Quinton, Cowan, \& Watson, 1996]). High RWA individuals prefer to submit to established authorities; are willing to express aggression towards the target of their prejudices; and adhere to traditional, accepted social conventions (Altemeyer, 1996, 1998). Although some research has found high RWA individuals to be prejudiced against African Americans (Altemeyer, 1998), other research has not (Whitley, 1999), perhaps because of the prohibition against public displays of anti-Black prejudice. Authority figures who rail against homosexuals in their community would be less likely early in the $21^{\text {st }}$ century to condone racial prejudice (Whitley \& Kite, 2006). Their followers may oppose racial discrimination at the same time they support discrimination against homosexuals. 
Authoritarians (individuals high in RWA) look to those they perceive to be in authority to guide their attitudes towards other groups. Sometimes called follower's authoritarianism (Roccato \& Ricolfi, 2005), RWA differs from the dominating preferences of those high in SDO (Altemeyer, 1998). Authoritarian support for social conventions and tradition stems from their deference to authority. "Authoritarians reject the idea that people should develop their own ideas of what is moral and immoral, since authorities have already laid down the laws" (Altemeyer, 1996, p. 11). As a measure of preference for equality or group-based domination, one's SDO does not indicate a preference for tradition or deference to authority. Because these constructs tap different belief systems, there are generally low correlations between the SDO and RWA scales; from nonsignificance (Pratto et al., 1994) to $r=.24$ (Altemeyer, 1998), for example.

\section{Discrimination and Practice in Gifted Education}

Several practices in gifted education have the potential to be affected by authoritarian or dominating attitudes. Gifted children may belong to any number of arbitrary groupings. In addition to their membership in the heterogeneous group of gifted students, they may be from different ethnic groups, different religious backgrounds, different political leanings, or different income levels. Depending on the predominant definition of giftedness, the characteristics they share may be their performance on a standardized test, the grades assigned by their teachers, or the judgment given to their creative products. How each of these various methods of identifying gifted students is applied may be discriminating to any of the other arbitrary groups to which children may belong. Underrepresentation of students of color in gifted programs (Ford, Harris, Tyson, 
\& Trotman, 2002; Office of Educational Research and Improvement, 1993) suggests that some form of racial discrimination is occurring in identification practices.

\section{Identification}

One of the persistent challenges in the field of gifted education has been finding appropriate, practical means of identifying gifted students. From the time of Terman's (1925) use of an IQ test to identify subjects for his study of genius, various approaches to identification have been taken. Tests, assessment of student products, recommendations from multiple sources, all have been used to identify students to receive special services. None of these approaches has been without detractors. Tests of intelligence are frequently criticized for their cultural bias and the inequity that results from their use in identification (Ford, 2003; Frasier, 1991; Mills \& Tissot, 1995). Getzels and Jackson (1958) proposed that creativity tests indicated students' abilities for divergent thinking and could successfully identify students for gifted programs. Since that time, the validity of creativity tests has been challenged, as has their usefulness in identifying students for academic gifted programs (Borland, 2008). Achievement tests alone are generally not recommended for identification into a gifted program (Coleman \& Cross, 2005), but they are sometimes used to identify students for further testing. This practice is discriminating to students from low SES and minority backgrounds, whose disadvantage is likely to eliminate them from even this first level indicator (Richert, 1991). Student products may also be used in the identification process and particular success has been reported in using these among underrepresented populations (Wright \& Borland, 1993). Recommendations from parents, teachers, and the students themselves may be used as a means of identifying students for gifted programs, although rarely would these be used without 
some other screening method (Coleman \& Cross, 2005). How each of these identification methods relates to beliefs about intergroup behavior is one question of this study.

\section{Gifted Programming}

Gifted students may receive differentiated lessons in their regular classrooms. Schools often prefer this option, because of the perception that it requires few resources, but significant effort is required to offer true differentiation. Some schools may claim to be differentiating instruction when, in reality, no differentiation has occurred (Cassady et al., 2004). In another option for providing services, students may be pulled out of the regular class for an hour or two a few times a week for challenging lessons. Cluster groups of different ability levels may be formed in the regular class, with instruction differentiated for each group. Some schools offer self-contained classes for gifted students, who spend the entire school day with gifted peers in an environment intended to meet their academic needs. In residential academies, high school students are surrounded day and night by their gifted peers in an academically challenging setting. Elite private schools with an emphasis on gifted curricula are available for those who have access and the economic means to attend. This study explores preferences for each of these programming options.

Cooperative learning in mixed-ability groups has been criticized as detrimental to the academic progress of gifted students, particularly through its effects on motivation as less able group members exploit the gifted members' abilities (e.g., Fiedler, Lange, \& Winebrenner, 2002; Robinson, 1990), but this exploitation has not been supported through empirical research. Neber, Finsterwald, and Urban (2001) reviewed the available studies on high-ability, high-achieving students and cooperative education. They found 
very few studies using students identified as gifted. Among those studies, there were positive outcomes reported for the gifted students placed in heterogeneous, mixed-ability groups. Huss (2006) argues that negative perceptions may stem from improper implementation of cooperative learning, with a lack of attention to individual interdependence in appropriately challenging assignments.

Despite its criticisms in the gifted literature, cooperative learning is one of the few educational practices found to be effective in reducing prejudice (Johnson \& Johnson, 2000; Slavin, 2001). This educational technique fulfills the four conditions of intergroup contact proposed by Allport (1954) to be necessary for improving intergroup relations:

1. Members of each group must have equal status in the situation.

2. The groups must work cooperatively to achieve common goals.

3. The situation must allow participants to get to know each other as individuals (referred to as acquaintance potential).

4. The intergroup effort must have the support of authorities, law, or custom (referred to as institutional support). (Whitley \& Kite, 2006, p. 510) When members of different groups - racially diverse or mixed-ability students, for example - come together in situations that meet these four conditions, they have an opportunity to challenge the stereotypes each may hold about outgroup members. Working together towards a common goal such as good grades or teacher approval allows students to learn first hand about the individual characteristics of the diverse members of their cooperative group. Aronson's (1978) Jigsaw Classroom is a cooperative learning program created to relieve intergroup tensions that came with desegregation of the Austin, Texas public schools. Subsequent research found reduced 
prejudice and stereotyping, accompanied by improved affective outcomes (Aronson \& Bridgeman, 1979; Bridgeman, 1981).

\section{Method}

\section{Hypotheses}

In this study, we hypothesized that subjects high in either SDO or RWA would resist cooperative learning for gifted students, reasoning that high SDO subjects would prefer to maintain dominance and would not appreciate a practice that builds egalitarian sentiment in the classroom. Considering the varieties of prejudice associated with high RWA scores, we predicted that these subjects would reject cooperative learning, preferring an insular classroom that does not allow for intergroup contact.

This study was designed to test the hypothesis that some supporters of gifted education will prefer hierarchy-enhancing practices that favor the dominant group, such as IQ testing for identification and self-contained classes for gifted students, and oppose hierarchy-attenuating practices, such as cooperative learning. We hypothesized that rightwing authoritarians would have similar preferences due to the correlations to prejudice found in other studies.

\section{Participants}

Subjects over 18 years of age were solicited to participate in an anonymous online survey through emails sent to the address lists of various professionals in the field of gifted education. The solicitation contained the following statement:

We are looking for parents, teachers, researchers, administrators, and gifted persons age 18 and over who are supporters of gifted education to participate in this study. 
The original email list contained addresses of researchers and other professionals who serve as manuscript reviewers or who have submitted manuscripts to be considered for publication in the Journal for the Education of the Gifted, a prestigious research journal in gifted education. Other researchers forwarded the survey solicitation to their email lists, expanding the reach to a diverse population of supporters of gifted education. A link to the survey was posted on two popular gifted education websites: www.giftedkids.about.com and www.hoagies.com. Solicitations were also published in the journals Gifted Child Today, Journal for the Education of the Gifted, and Roeper Review. Those receiving the emails or viewing the solicitation were highly likely to be supportive of gifted education, simply by virtue of their choice to enter the websites, subscribe to the journals, or through their professional connection to research in the field.

Through these various outlets, a sample of 341 (female $n=290$, male $n=49$ ) selfidentified supporters of gifted education responded to the online survey over a 7-month period. Internet access was required for participation, perhaps skewing the socioeconomic status of the subject pool, Subjects were also either exceptionally active in the field, subscribing to, publishing or reviewing articles for major journals, or they were exceptionally interested in gathering more information through the websites where solicitations appeared. Further demographics of this unique sample are described in the Results.

Support for gifted education could come from all quarters: from parents of gifted children, from school officials and teachers, from adult gifted persons, from legislators and businessmen. The sample of this study was unique in its recruitment. Those tangentially supporting gifted education would not likely have been reached, nor would 
those who know little about the field. By soliciting only those well-entrenched in the field through their professional connections and those interested in learning more about gifted education by exploring informational websites, our study was assured of reaching individuals who were definitely committed to support for the field. Casting a broader net might have included subjects not as invested in gifted education, but may also have attracted supporters not represented here.

\section{Instruments}

Demographics/Preferred Practice. Study participants responded to questions concerning their involvement in gifted education along with demographic information. To assess their preference for the practices identified as potentially influenced by SDO and RWA, subjects were asked to choose only one response to the questions concerning the best identification and programming practices and beliefs about cooperative education with gifted learners (see Table 1). Because our hypothesis sought to determine what specific preferences for identification of gifted children may be associated with SDO and RWA, no choice was offered for multiple methods. By forcing respondents to choose one of these methods, variance between preferred identification practice and levels of SDO or RWA could be seen.

\section{INSERT TABLE 1 ABOUT HERE}

Social Dominance Orientation. Questions from the Jost and Thompson (2000) 16-item SDO scale were interspersed among questions from the RWA scale and the Marlowe-Crowne Social Desirability Scale. All scales used a 7-point Likert scale, with 1 
being "Strongly Disagree" and 7 being "Strongly Agree." Jost and Thompson identified a problem with the most frequently used Pratto et al. (1994) SDO scale, in which half of the questions were worded positively and half negatively. The eight items reflective of opposition to equality (OEQ) were worded in such a way that agreement with them resulted in lower SDO and the eight items reflecting group-based dominance (GBD) were worded so that agreement with them resulted in higher SDO. The Jost and Thompson scale resolves this problem with balanced wording that more clearly identifies the two dimensions of SDO. OEQ and GBD scores were calculated as means of the 8 items in each factor. Sample questions are in Table 2. Reliability was acceptable for this sample $(\alpha=.85)$.

\section{INSERT TABLE 2 ABOUT HERE}

A high SDO score is determined relative to the sample. For example, in Sidanius and Pratto's (1999) report of 39 studies using their 7-point Likert SDO scale, for approximately 10,000 respondents, the average mean for each study ranged from 1.59 (a sample of 56 Los Angeles public defenders) to 3.83 (a sample of 59 Los Angeles police officers). The average mean of all 39 studies was 2.6 with a standard deviation of .79 . Although only items above 4 indicate true agreement with the dominance-oriented statement, researchers look upon relative differences as meaningful and have found them to correlate highly with measures of prejudice or support for hierarchy-enhancing policies (Sidanius \& Pratto). 
Right-Wing Authoritarianism. This study used the 19-item short form of the RWA scale by Duckitt and Fisher (2003), adapted from Altemeyer (1996). Reliability for this sample was high $(\alpha=.94)$. Scores are the aggregated mean of the 19 RWA items on a 7-point scale, from 1=Strongly Disagree to 7=Strongly Agree.

Marlowe-Crowne Social Desirability Scale. The SDO and RWA scales include statements that may elicit socially undesirable responses. To test respondents tendency to answer questions the way they believe others would want them to, a social desirability scale was included. This scale indicates the respondent's general desire for social approval using a 7-point Likert-type response, with 1=Strongly Disagree and 7=Strongly Agree. The 11-item short form (Reynolds, 1982) of the Marlowe-Crowne scale (MCS) had minimally acceptable reliability in this sample, with Cronbach's alpha $=.67$ (DeVellis, 2003).

\section{Supporter Demographics}

\section{Results}

This committed group of supporters was not a diverse group, as can be seen in Table 3. Overwhelmingly female, White, well-educated, and upper middle class, more than two-thirds of the survey respondents had an official role in gifted education as either a teacher, trainer of $\mathrm{G} / \mathrm{T}$ professionals, counselor or psychologist, or researcher $(n=240$, $70 \%$ ). Participants ranged in age from 18 to 80 , with anywhere from a few months to as many as 55 years of involvement in gifted education. The majority of respondents were parents of gifted children $(n=249)$ and most of their children attended public schools $(n=177)$. Not all of the respondents considered themselves to be gifted persons. Threefourths responded "Yes" to the statement "I am a gifted person." 


\section{INSERT TABLE 3 ABOUT HERE}

\section{Supporter Attitudes}

Unfortunately, not all respondents completed all measures. Of the 316 who completed the SDO scale, the overall mean of SDO $(M=2.40, S D=.79)$ is similar to other studies utilizing a 7-point Likert SDO scale (e.g., Sidanius \& Pratto, 1999). The overall mean of RWA was $2.82(S D=1.14, n=318)$, lower than the average near the midpoint reported by Duckitt (1993) and Altemeyer (1981, 1988). SDO and RWA scores were highly correlated, $r=.57, p<.001$.

To explore the question of interest to this study - Is there a relationship among SDO, RWA, MCS, and a preference for different gifted education practices (i.e., identification, classroom practice)? - we first looked for differences in SDO and RWA between the different groupings. Using univariate ANOVA with SDO or RWA as the dependent variables and MCS as the covariate to eliminate subjects' bias for socially desirable responding, we looked for mean differences by gender, age, income level, education, parent of a G/T child or not, type of school children attended, role in gifted education (teacher or other professional vs. not), and gifted person or not. The sample was too unevenly distributed to make comparisons by ethnicity or country of residence, with fewer than $10 \%$ non-White or living outside of the USA.

Once the Bonferroni post-hoc correction was made for the multiple comparisons (i.e., gender, age, education, etc.), none of the SDO mean comparisons were significant at the .05 significance level. Using Analysis of Covariance (ANCOVA), RWA differed 
significantly between education levels even when using the Bonferroni correction for multiple comparisons, $F(4,304)=6.03, p<.001$. There was, however, no practical difference between scores, with a low effect size of partial eta squared $=.07$. These findings were unexpected and contrary to our hypotheses that supporters of gifted education with high SDO or RWA would prefer different practices.

\section{Preferred Gifted Education Practice}

Because our hypotheses were not supported, a means of further exploring the relationship among SDO, RWA, MCS and preference for different practices in gifted education was needed. A cluster analysis of the responses to questions concerning practice in gifted education was determined to be the most appropriate next step. By identifying how respondents clustered together in their preference for certain practices, the relationship with the variables of interest could be pursued. The first question, "The primary purpose of gifted education is..." was not included in this analysis, as $99 \%$ of the valid responses $(n=325)$ to this question were "to help students with gifts and talents achieve their maximum potential." The questions and their response options are listed in Table 1.

Four variables were used in the conduct of the latent class analysis (LCA), a method appropriate for cluster analysis of categorical variables: BESTID ("I believe the best method of identification of gifted students is..."; grouped by all test options vs. all other options), COOPLRN ("Cooperative learning should be used with gifted students and their nongifted peers...”), COOPBEN (“Cooperative learning in mixed-ability groups primarily benefits gifted students...") and BESTPGM ("It is in the best interest of gifted 
students to be placed in..."). Results of the Bayesian Information Criterion (BIC) were minimized for the model with 2 latent groups, and the $\chi^{2}$ test of fit was 69.105 , with a $p$ value of 0.9948 , suggesting adequate fit for the 2 latent groups solution. Table 4 includes the number and proportion of individuals in each group responding to each item category. For this analysis, only respondents who answered all questions of interest, including the SDO, RWA, and MCS instruments were used $(n=218)$. Group means are presented in Table 5.

\section{INSERT TABLE 4 ABOUT HERE} INSERT TABLE 5 ABOUT HERE

Preference for identification practice was not different between the two groups. To the key questions concerning cooperative learning, Group 1 members indicated a strong preference to avoid cooperative learning with gifted children, with $80 \%$ responding it should seldom be used with gifted children and 73\% responding that it has no benefit to gifted children. This group overwhelmingly (69\%) selected self-contained classes as "in the best interest" of gifted students. This preference in Group 1 for avoiding cooperative learning and for removing gifted children from shared environments with their nongifted peers led to the name Individualists for this group. Their preference appears to be related to their lower desire to defer to authority, as the relationship with RWA indicates.

Group 2 members strongly believed that cooperative learning benefits gifted children socially, with $93 \%$ choosing this option. Seventy-four percent of Group 2 
members indicated that cooperative learning with gifted children and their nongifted peers should happen often. The programming options Group 2 members preferred all begin in the regular classroom. Less than a quarter of Group 2 members chose programming options that separate gifted children from their nongifted peers, compared to nearly $3 / 4$ of the Individualists. These opposite preferences in Group 2 led to the group name Communitarians. Figures 1 through 4 are graphic depictions of group differences.

In order to determine whether the group membership was associated with the SDO, MCS and RWA scores, logistic regression was used. In this analysis, the group served as the dependent variable, while the three independent variables were the scores of interest. The results of this analysis appear in Table 6. The positive slope for SDO indicates that the higher the score on this variable, the greater the likelihood of being in Group 1 (Individualists), while the negative slope for RWA indicates that higher scores on this variable were associated with a lower likelihood of being in Group 1. MCS was not significantly associated with group membership.

\section{INSERT TABLE 6 ABOUT HERE}

\section{Discussion}

\section{Group Differences}

Individualists and Communitarians were similar in many regards. With demographic numbers being fairly small in many cases, the scale used in Figure 4 is the number of group members rather than a percentage. In most demographic categories, Individualists and Communitarians had remarkably similar numbers. There were the 
same numbers of $\mathrm{G} / \mathrm{T}$ teachers in secondary education in both groups $(n=17)$, for example. In elementary education, however, there were considerably more $\mathrm{G} / \mathrm{T}$ teachers in the Communitarian group ( $n=23$ vs. $n=9$ ). There were also more Individualists $(n=68)$ than Communitarians $(n=51)$ among Master's degree and Ph.D. holders and more Communitarians among those with less education (Bachelor's/Graduate school Communitarian $n=43$ vs. Individualist $n=31$; High School/Associate's Communitarian $n=15$ vs. Individualist $n=10$ ). More G/T researchers were in the Individualist group $(n=25)$ than in the Communitarian group $(n=17)$. Counselors or psychologists were more likely to be in the Communitarian group $(n=13)$ than the Individualist group $(n=7)$. The few non-White respondents fell primarily into the Communitarian group ( $n=14$ vs. Individualist $n=3)$.

Parceling out the parents of gifted children who also have an official role as teacher, administrator, or other such occupations, there were more Individualists ( $n=49)$ than Communitarians $(n=38)$ among parents who did not have an official $\mathrm{G} / \mathrm{T}$ role. Perhaps the greatest difference between groups can be seen in those who responded positively to the statement "I am a gifted person." Individualists $(n=89)$ were more likely to say this than Communitarians $(n=65)$. This difference may be because Communitarians actually would not meet the various criteria used to identify giftedness, or they may see the claim of giftedness as a socially undesirable response.

\section{RWA and SDO Correlations}

Most studies using both the RWA and SDO scales find very low correlations between the two (e.g., $r=.11$, Altemeyer, 1998; $r=.14$, Pratto et al., 1994). In this sample, however, SDO and RWA were significantly correlated with a fairly high coefficient: 
$r=.57, p<.001, n=341$. This may be associated with the sample of this study, few of whom were of college age. Duckitt (2001) proposed that the consistent finding of higher correlations between SDO and RWA among older subjects is associated with the socialization process occurring during adolescence. With maturity, beliefs about authority and social dominance that were developing independently will come to influence one another, leading to a convergence of scores in adult samples. Numerous studies with adult subjects found higher correlations between RWA and SDO in adult samples than in student samples (see Roccato \& Ricolfi, 2005, for a review). High correlations such as the one in this sample are not the norm, however, even for adult samples. Such high correlations are normally found in countries where there are greater polarizations in ideology in the sociopolitical system. As Roccato and Ricolfi describe, "in countries characterized by minor ideological contrast (e.g., the United States, Canada, South Africa, and Poland) political behaviors are less structured [than in countries characterized by strong ideological contrast]; accordingly, people's RWA and SDO scores are often independent of each other." Age and societal ideological contrast are the two factors hypothesized to influence the correlation between RWA and SDO. The only sample among the 51 reviewed by Roccato and Ricolfi in a country with weak ideological contrast such as the US with a correlation that approaches the one found here, was conducted with 97 U.S. women ( $r=.46$; Wang, 1999). Although still high, males in this study had a lower correlation than females ( $r=.47$ vs. $r=.60, p<.01)$. Considering the female majority in this study (86\%), this may be evidence that gender is an additional influence on the RWA/SDO correlation, a finding not previously reported.

\section{Maximizing Student Potential}


Perhaps not surprisingly for supporters of gifted education, $99 \%$ of respondents believed that the purpose of gifted education is to maximize a child's potential. This group is, by the very nature of their advocacy, supportive of this educational goal for gifted children. The results of this study, however, suggest that not all of these individuals are interested in pursuing this objective for all students. Applying the research in the psychology of prejudice to the preferred practice of supporters of gifted education, it was expected that elitist attitudes would become apparent through supporters' opposition to equality or desire for group-based domination and a desire to maintain distance from other groups. Insubstantial differences were seen among the different demographic groups on SDO, however. The lack of diversity in SDO scores in this sample is contrary to our original hypothesis, that support for different practice would be related to different attitudes about intergroup relations. Instead, respondents' preference to defer to authority appears to make the difference in support of some practices over others.

The research supporting the relationship between RWA and various forms of prejudice is substantial. Rather than the expected finding that RWA scores would predict a desire to maintain a separation between gifted and nongifted students or between those traditionally identified gifted who are usually in the dominant group (White, upper or middle class) and students from other groups, RWA scores in this sample are associated with a preference for inclusion. According to Altemeyer (1998), "right-wing authoritarians believe strongly in submission to established authorities and the social norms these authorities endorse" (p. 86). The social norm these authoritarians express through their choices of gifted practice is one of inclusion. Based on their preference for 
cooperative learning, it is possible that these supporters of gifted education reject the exclusive nature of self-contained classrooms.

Individualists may reject the social norm of inclusion in favor of practices that are of greatest academic benefit to gifted students. In their study of more than 1,000 elementary school students, Delcourt, Loyd, Cornell and Goldberg (1994) found that students in special schools, separate class programs, and pull-out programs "showed substantially higher levels of achievement than both their gifted peers not in programs and those attending Within-Class programs" (p. vii). In a meta-analysis of 51 studies Kulik (1992) found only small positive effects of homogeneous classes on high-ability learners, perhaps because the grouping was done without curricular modifications. Kulik's analysis indicates that simply separating gifted students from their nongifted peers does not provide significant academic advantages. There is considerable evidence that self-contained classes with accelerated curricula do provide academic advantages (Rogers, 2007). Individualists' preference for these separate classes for gifted students is in keeping with research findings regarding the academic benefits of self-contained classes.

Differentiation in a heterogeneous classroom was the preferred programming option for Communitarians. Individualists may reject this option not because it cannot serve gifted students adequately, but because they perceive that it does not. The challenges of providing an adequate differentiated curriculum are great, and require training and commitment for success (Tomlinson, 2003; VanTassel-Baska \& Stambaugh, 2005). Teachers must be willing to engage in new methods of curricular planning and classroom management and administrators must be supportive as well (Hertberg-Davis \& 
Brighton, 2006). Individualists may be rejecting this option because they perceive its implementation failures, not simply because they are opposed to gifted students in the regular classroom as a higher SDO might have indicated. Van Tassel-Baska, Quek and Feng (2007) found that teachers may not always meet their objective of actual differentiation in the classroom. Successful differentiation might find support among Individualists, but unsuccessful differentiation is not in the best interest of gifted students. With their lower desire to defer to authority, Individualists are willing to say so. Communitarians may not perceive differentiation as a failed practice, either having seen successes in their experience or being unfamiliar with the potential for unsuccessful implementation. This latter possibility seems unlikely, given the high numbers of individuals with an official role in gifted education in both groups. Teachers, administrators, counselors, and researchers are likely to have at least been exposed to the notion of unsuccessful differentiation. The social norm of inclusion may be stronger for Communitarians than a fear of failed practice in the classroom.

Robinson (1990) has criticized cooperative learning in mixed-ability groups for the opportunity it offers for negative social behaviors, such as social loafing or freeriding, that may impede gifted students' learning. Despite this criticism, little empirical research exists regarding the benefits or detriments of cooperative learning with gifted students (Neber, et al., 2001). The few methodologically sound studies of cooperative learning found in Neber et al.'s meta-analysis had positive benefits both socially and academically for gifted students. There is by no means a definitive conclusion that cooperative learning is an ineffective or harmful practice for gifted students. Individualists, however, appear convinced that it should seldom be used with gifted 
students and is of no benefit to them. Considering the lack of empirical evidence for this belief in light of the advantages seen to reductions in prejudice, societal equity goals suggest that researchers in gifted education should be taking a closer look at cooperative learning.

\section{Communitarian Gifted Education}

Can gifted students achieve their maximum potential with a Communitarian approach to gifted education? Such a program would favor differentiated curriculum in a heterogeneous classroom, with frequent use of cooperative learning. Rogers' (2007) synthesis of research suggests that some sort of homogeneous grouping of gifted students is beneficial both academically and socially, provided the curriculum students receive is appropriately differentiated. Not allowing students to be grouped in some way with their intellectual peers will almost certainly limit their achievement. Research is inconclusive as to the effects of cooperative learning, but there is not evidence that its appropriate use would inhibit gifted students' achievement.

It is possible that those higher in RWA are willing to sacrifice the gifted on the alter of the inclusion norm. Altemeyer (1996) states, "right-wing authoritarians are predisposed to control the behavior of others through punishment.... Anyone could become the target of authoritarian aggression, but unconventional people (including 'social deviants') and conventional victims of aggression are attacked more readily than others" (p. 10). This aggression is the source of discriminatory behavior when authorities approve of prejudice towards the target. The acceptance of discrimination towards homosexuals with the approval of leading religious figures is an example of this. Our sample of supporters of gifted education may see the gifted, particularly those highly 
gifted, as "unconventional people" who must stay in the traditional classroom, either as punishment (e.g., boredom, lack of challenge) for their deviance or in service of the higher priority, the tradition of inclusion. This perspective may be the reason Communitarians were less likely to respond "yes" to the statement "I am a gifted person," similar to gifted students who attempt to avoid the stigma of being identified as gifted (Cross, Coleman \& Terhaar-Yonkers, 1991).

Authoritarians in this study, the Communitarians, look very much like their counterparts in the Individualist group. Although there are differences, they have similar education levels, serve in similar roles in gifted education, and have similar incomes. All of these supporters agreed that the purpose of gifted education is to "help students with gifts and talents achieve their maximum potential," so any superordinate goal to preserve the inclusion norm is not likely one they even recognize. Their choices of inclusive practices, however, may be seen as counter to the goal of maximizing potential when concern for the inclusion norm is not present, as in the case of the Individualists.

\section{Limitations}

One limitation of this study is the means of acquiring the sample. A larger population of supporters in parent support groups or professional organizations might result in different sample demographics. It is difficult to situate these findings in the larger societal context without the perspective of a group of nonsupporters or those who are neutral to issues affecting gifted education. A study comparing the preference for gifted education practice in these populations would provide a valuable perspective.

The SDO and RWA instruments designed and validated in studies with thousands of respondents (e.g., Altemeyer, 1998; Duckitt, 2001, Pratto, et al., 1994; Sidanius \& 
Pratto, 1999 ) contain items that are clearly controversial. They address attitudes toward firmly held beliefs and engender strong feelings among respondents. The need to include a social desirability scale to determine those who are responding as they feel they should believe rather than how they do believe indicates the contentious nature of this type of research. Some potential respondents may have chosen not to participate because of their reaction to the survey items. Despite a desire to maintain a delicate sensibility, such difficult questions are important to ask.

\section{Conclusion}

The supporters of gifted education in this study represent two camps that have not previously been acknowledged in the literature. When advocating for gifted programming, supporters may prefer different practices for reasons of which they are unaware. To please both Individualists and Communitarians, gifted programming will need to recognize what is meant by "best" for gifted students. What is best to one camp may not appear so in the other, yet both will be describing their goals with the same words. When what is best for gifted students ignores their role as members of a community or inhibits their ability to achieve to their maximum potential, resentment in one camp or the other is inevitable, even among those who identify themselves as supporters.

Like all students, gifted students need an appropriate education. The dilemma for supporters of gifted education is how to advocate for the unique needs of children with gifts and talents without alienating the much larger population that does not have similar abilities. In an era when public schools are struggling for their very survival (Cooper \& Randall, 2008), the goal of minimum competency is sometimes the only one that appears 
attainable. In addition to satisfying the educational needs of gifted students, improving practices that serve these students in the regular classroom could have the added bonus of benefiting all students. When maximizing potential for all students is the broader goal, the time that gifted students need to be with their intellectual peers may not be met with resentment (e.g., Sapon-Shevin, 1994). 


\section{References}

Adorno, T. W., Frenkel-Brunswick, E., Levinson, D. J., \& Sanford, R. N. (1950). The authoritarian personality. New York: Harper and Row.

Allport, G. W. (1954). The nature of prejudice. New York: Perseus.

Altemeyer, R. A. (1981). Right-wing authoritarianism. Winnipeg: University of Manitoba Press.

Altemeyer, R. A. (1988). Enemies of freedom: Understanding right-wing authoritarianism. San Francisco: Jossey-Bass.

Altemeyer, R. A. (1996). The authoritarian specter. Cambridge, MA: Harvard University Press.

Altemeyer, B. (1998). The other "authoritarian personality”. In M. P. Zanna (Ed.) Advances in Experimental Social Psychology, vol. 30, (pp. 47-92). San Diego, CA: Academic Press.

Apple, M. W. (1990). Ideology and curriculum (2 $2^{\text {nd }}$ ed.). New York: Routledge.

Aronson, E. (1978). The jigsaw classroom. Beverly Hills, CA: Sage.

Aronson, E. \& Bridgeman, D. (1979). Jigsaw groups and the desegregated classroom: In pursuit of common goals. Personality and Social Psychology Bulletin, 5(4), 438446.

Baker, B. D., \& Richards, C. E. (1998). Equity through vouchers: The special case of gifted children. Educational Policy, 12, 363-379.

Borland, J. H. (2008). Identification. In J. A. Plucker \& C. M. Callahan (Eds.), Critical issues and practices in gifted education: What the research says (pp. 261-280). Waco, TX: Prufrock Press. 
Bridgeman, D. (1981). Enhanced role-taking through cooperative interdependence: A field study. Child Development, 52, 1231-1238.

Cassady, J. C., Speirs Neumeister, K. L., Adams, C. M., Cross, T. L., Dixon, F. A., \& Pierce, R. L. (2004). The Differentiated Classroom Observation Scale. Roeper Review, 26(3), 139-146.

Coleman, L. J., \& Cross, T. L. (1988). Is being gifted a social handicap? Journal for the Education of the Gifted, 11, 41-56.

Coleman, L. J., \& Cross, T. L. (2005). Being gifted in school (2 $2^{\text {nd }}$ ed.). Waco, TX: Prufrock Press.

Cooper, B. S., \& Randall, E. V. (2008). Fear and privatization. Educational Policy 22(1), 204-227.

Cramond, B., \& Martin, C. E. (1987). Inservice and preservice teachers' attitudes toward the academically brilliant. Gifted Child Quarterly, 31(1), 15-19.

Cross, J. R., \& Cross, T. L. (2005). Social dominance, moral politics, and gifted education. Roeper Review, 28(1), 21-29.

Cross, T. L., al Lawati, F., Frazier, A. D., \& Cross, J. R. (2007, November). Two schools for gifted students in one building: A quantitative exploration of different cultures. Presentation at the annual meeting of the National Association of Gifted Children, Minneapolis.

Cross, T. L., Coleman, L. J., \& Terhaar-Yonkers, M. (1991). The social cognition of gifted adolescents in schools: Managing the stigma of giftedness. Journal for the Education of the Gifted, 15(1), 44-55. 
Delcourt, M. A. B., Loyd, B. H., Cornell, D. G., \& Goldberg, M. D. (1994). Evaluation of the effects of programming arrangements on student learning outcomes. (Monograph of the National Research Center on the Gifted and Talented, No. 94108). Storrs, CT: University of Connecticut.

Devellis, R. F. (2003). Scale development: Theory and applications $\left(2^{\text {nd }} e d\right)$. Thousand Oaks, CA: Sage.

Duckitt, J. (1993). Right-wing authoritarianism among White South African students: Its measurement and correlates. The Journal of Social Psychology, 133(4), 553-563.

Duckitt, J. (2001). A dual-process cognitive-motivational theory of ideology and prejudice. In M. P. Zanna (Ed.), Advances in Experimental Social Psychology, vol. 33, (pp. 41-113). San Diego, CA: Academic Press.

Duckitt, J. \& Fisher, K. (2003). The impact of social threat on worldview and ideological attitudes. Political Psychology, 24(1), 199-222.

Duncan, L. E., Peterson, B. E. \& Winter, D. G. (1997). Authoritarianism and gender roles: Toward a psychological analysis of hegemonic relationships. Personality and Social Psychology Bulletin, 23, 41-49.

Ekehammar, B., Akrami, N., Gylje, M., Zakrisson, I. (2004). What matters most to prejudice: Big five personality, social dominance orientation, or right-wing authoritarianism? European Journal of Personality, 18, 463-482.

Fiedler, E. D., Lange, R. E., Winebrenner, S. (2002). In search of reality: Unraveling the myths about tracking, ability grouping, and the gifted. Roeper Review, 24(3), 108111. 
Ford, D. Y. (2003). Desegregating gifted education: Seeking equity for culturally diverse students. In J. H. Borland (Ed.) Rethinking gifted education (pp. 143-158). New York: Teachers College Press.

Ford, D. Y., Harris, J. J., Tyson, C. A., \& Trotman, M. F. (2002). Beyond deficit thinking: Providing access for gifted African American students. Roeper Review, 24(2), 52-58.

Frasier, M. M. (1991). Gifted minority students: Reframing approaches to their identification and education. In N. Colangelo \& G. A. Davis (Eds.) Handbook of gifted education ( $2^{\text {nd }}$ ed.; pp. 498-515). Needham Heights, MA: Allyn \& Bacon.

Gagné, F. (1983). Perceptions of programs for gifted children: Agreement on principles, but disagreement over modalities. B. C. Journal of Special Education, 7, 113-127.

Getzels, J. W., \& Jackson, P. W. (1958). The meaning of "giftedness" - an examination of an expanding concept. Phi Delta Kappan, 46, 75-77.

Giroux, H. A. (2005). Schooling and the struggle for public life: Democracy's promise and education's challenge. Boulder, CO: Paradigm.

Hertberg-Davis, H. L., \& Brighton, C. M. (2006). Support and sabotage: Principals' influence on middle school teachers' responses to differentiation. Journal of Secondary Gifted Education, 17(2), 90-102.

Huss, J. A. (2006). Gifted education and cooperative learning: A miss or a match? Gifted Child Today, 29 (4), 19-23.

Johnson, D. W., \& Johnson, R. T. (2000). The three Cs of reducing prejudice and discrimination. In S. Oskamp (Ed.), Reducing prejudice and discrimination (pp. 239-268). Mahwah, NJ: Erlbaum. 
Jost, J. T., \& Thompson, E. P. (2000). Group-based dominance and opposition to equality as independent predictors of self-esteem, ethnocentrism, and social policy attitudes among African Americans and European Americans. Journal of Experimental Psychology, 36, 209-232.

Kulik, J. A. (1991). An analysis of the research on ability grouping: Historical and contemporary perspectives. (Monograph of the National Research Center on the Gifted and Talented, No. 9204). Storrs, CT: University of Connecticut.

Levin, S. (2004). Perceived group status differences and the effects of gender, ethnicity, and religion on social dominance orientation. Political Psychology, 25, 31-48.

McCoach, D. B., \& Siegle, D. (2007). What predicts teachers' attitudes towards the gifted? Gifted Child Quarterly, 51(3), 246-255.

Mills, C. J., \& Tissot, S. L. (1995). Identifying academic potential in students from under-represented populations: Is using the Raven's Progressive Matrices a good idea? Gifted Child Quarterly, 39, 209-217.

Morris, S. K. (1987). Student teachers' attitudes towards gifted students. Creative Child and Adult Quarterly, 12, 112-114.

Neber, H., Finsterwald, M., \& Urban, N. (2001). Cooperative learning with gifted and high-ability students: A review and meta-analyses of 12 studies. High Ability Studies, 12(2), 199-214.

Oakes, J. C. (1985). Keeping track: How schools structure inequality. New Haven, CT: Yale University Press. 
Office of Educational Research and Improvement, U.S. Department of Education. (1993). National excellence: A case for developing America's talent. Washington, DC: U.S. Government Printing Office.

Quinton, W. J., Cowan, G., \& Watson, B. D. (1996). Personality and attitudinal predictors of support of proposition 187 - California's anti-illegal immigrant initiative. Journal of Applied Social Psychology, 26, 2204-2223.

Pratto, F., Sidanius, J., Stallworth, L. M., \& Malle, B. F. (1994). Social dominance orientation: A personality variable predicting social and political attitudes. Journal of Personality and Social Psychology, 67, 741-763.

Reynolds, W. M. (1982). Development of reliable and valid short forms of the MarloweCrowne Social Desirability Scale. Journal of Clinical Psychology, 38(1), 119125.

Richert, E. S. (1991). Excellence with equity in identification and programming. In N. Colangelo \& G. A. Dayis (Eds.) Handbook of gifted education ( $2^{\text {nd }}$ ed.; pp. 7588). Needham Heights, MA: Allyn \& Bacon.

Robinson, A. (1990). Cooperation or exploitation? The argument against cooperative learning for talented students. Journal for the Education of the Gifted, 14, 9-27.

Roccato, M., \& Ricolfi, L. (2005). On the correlation between right-wing authoritarianism and social dominance orientation. Basic and Applied Social Psychology, 27(3), 187-200.

Rogers, K. B. (2007). Lessons learned about educating the gifted and talented: A synthesis of the research on educational practice. Gifted Child Quarterly, 51(4), 382-396. 
Sapon-Shevin, M. (1994). Playing favorites: Gifted education and the disruption of community. Albany, NY: State University of New York Press.

Schmitt, M. T., Branscombe, N. R., \& Kappen, D. M. (2003). Attitudes toward groupbased inequality: Social dominance or social identity? British Journal of Social Psychology, 42, 161-186.

Sidanius, J. \& Pratto, F. (1999). Social dominance: An intergroup theory of social hierarchy and oppression. Cambridge: Cambridge University Press.

Sidanius, J. \& Pratto, F. (2003). Social dominance theory and the dynamics of inequality: A reply to Schmitt, Branscombe, \& Kappen and Wilson \& Liu, British Journal of Social Psychology, 42, 207-213.

Slavin, R. E. (2001). Cooperative learning and intergroup relations. In J. A. Banks \& C. M. M. Banks (Eds.), Handbook of research on multicultural education (pp. 628634). San Francisco: Jossey-Bass.

Tannenbaum, A. (1962). Adolescent attitudes towards academic brilliance. New York: Teachers College Press.

Terman, L. M. (1925). Mental and physical traits of a thousand gifted children: Genetic studies of genius, Vol. 1. Stanford, CA: Stanford University Press.

Tomlinson, C. (2003). Fulfilling the promise of the differentiated classroom: Tools and strategies for responsive teaching. Alexandria, VA: Association for Supervision and Curriculum Development.

VanTassel-Baska, J., Quek, C., \& Feng, A. X. (2007). The development and use of a structured teacher observation scale to assess differentiated best practice. Roeper Review 29(2), 84-92. 
VanTassel-Baska, J., \& Stambaugh, T. (2005). Challenges and possibilities for serving gifted learners in the regular classroom. Theory into Practice, 44(3), 211-217.

Wang, A. Y. (1999). Gender and nature: A psychological analysis of ecofeminist theory. Journal of Applied Social Psychology, 29, 409-423.

Whitley, B. E. (1999). Right-wing authoritarianism, social dominance orientation, and prejudice. Journal of Personality and Social Psychology, 77(1), 126-134.

Whitley, B. E., \& Kite, M. E. (Eds.). (2006). The psychology of prejudice and discrimination. Belmont, CA: Thomson Wadsworth.

Whitley, B. E., \& Lee, S. E. (2000). The relationship of authoritarianism and related constructs to attitudes toward homosexuality. Journal of Applied Social Psychology, 30, 144-170.

Wright, L., \& Borland, J. H. (1993). Using early childhood developmental portfolios in the identification and education of young, economically disadvantaged, potentially gifted students. Roeper Review, 15(4), 205-210. 
Table 1. Survey Questions Concerning Practice in Gifted Education

The primary purpose of gifted education is

a. to keep students with gifts and talents separate from their less able peers.

b. to help students with gifts and talents achieve their maximum potential.

c. to fulfill requirements in the law.

Other (please specify)

I believe the best method of identification of gifted students is
a. IQ test scores
b. achievement test scores
c. creativity test scores
d. combination of test scores
e. student products
f. teacher recommendation
g. parent recommendation
h. student self-recommendation
i. student participation without identification

Cooperative learning should be used with gifted students and their nongifted peers
a. often.
b. seldom.
c. never.

Cooperative learning in mixed-ability groups primarily benefits gifted students
a. academically.
b. socially.
c. not at all.

It is in the best interest of gifted students to be placed in
a. heterogeneous classrooms with differentiated instruction.
b. pull-out programs.
c. cluster groups.
d. self-contained classes.
e. residential programs.
f. elite private schools.
g. homeschool environments. 
Table 2. Sample Survey Questions

Social Dominance Orientation (Jost \& Thompson, 2000)

If certain groups of people stayed in their place, we would have fewer problems.

No group of people is more worthy than any other. (-)

Treating different groups more equally would create more problems than it would solve. Right-Wing Authoritarianism (short form from Duckitt \& Fisher, 2003).

What our country really needs instead of more "civil rights" is a good stiff dose of law and order.

The real keys to the "good life" are obedience, discipline, and sticking to the straight and narrow.

The facts on crime, sexual immorality, and the recent public disorders all show we have to crack down harder on deviant groups and troublemakers, if we are going to save our moral standards and preserve law and order.

Social Desirability (Marlowe-Crowne scale short form from Reynolds, 1982)

No matter who I'm talking to, I'm always a good listener.

There have been occasions when I took advantage of someone. (-)

I'm always willing to admit it when I make a mistake.

I sometimes try to get even rather than forgive and forget. (-)

I am always courteous, even to people who are disagreeable. 
Table 3. Respondent Demographics.

\begin{tabular}{|c|c|c|c|c|c|c|c|}
\hline Gender & Female & Male & & & & & \\
\hline$n$ & 290 & 49 & & & & & \\
\hline Age Range & $18-25$ & $26-35$ & $36-45$ & $46-65$ & $>65$ & & \\
\hline$n$ & 16 & 64 & 117 & 136 & 7 & & \\
\hline Education & $\begin{array}{l}\text { High } \\
\text { School/ } \\
\text { Associate's }\end{array}$ & Bachelor's & $\begin{array}{l}\text { Graduate } \\
\text { School }\end{array}$ & Master's & Ph.D. & & \\
\hline$n$ & 30 & 55 & 54 & 104 & 98 & & \\
\hline & & & & & & & $y$ \\
\hline & & & & & & 1 & \\
\hline Ethnicity & White & Black & $\begin{array}{l}\text { Native } \\
\text { American }\end{array}$ & Hispanic & Chinese & Japanese & $\begin{array}{l}\text { Other } \\
\text { Asian/ } \\
\text { Pacific } \\
\text { Islander } \\
\end{array}$ \\
\hline$n$ & 307 & 6 & 4 & 4 & 4 & 2 & 3 \\
\hline Income & $<\$ 35,000$ & $<\$ 55,000$ & $<\$ 75,000$ & $\begin{array}{l}< \\
\$ 100,000\end{array}$ & $<\$ 200,000$ & $<\$ 400,000$ & $\$ 400,000+$ \\
\hline$n$ & 16 & 48 & 46 & 70 & 123 & 17 & 7 \\
\hline $\begin{array}{l}\text { Number in } \\
\text { Household }\end{array}$ & 1 & 2 & 3 & 4 & 5 & 6 & 7 or more \\
\hline$n$ & 41 & 72 & 71 & $112 y$ & 27 & 13 & 4 \\
\hline $\begin{array}{l}\text { Country of } \\
\text { residence }\end{array}$ & $\begin{array}{l}\text { United } \\
\text { States }\end{array}$ & Canada & Australia & $\begin{array}{l}\text { United } \\
\text { Kingdom }\end{array}$ & Other & & \\
\hline$n$ & 301 & 26 & 3 & 3 & 8 & & \\
\hline $\begin{array}{l}\text { Years in } \\
\text { gifted ed }\end{array}$ & $<2$ & $2-5$ & $6-10$ & $11-20$ & $20-30$ & $>30$ & \\
\hline$n$ & 31 & $92 \lambda \lambda$ & 66 & 65 & 38 & 27 & \\
\hline $\begin{array}{l}\text { Teacher of } \\
\text { gifted }\end{array}$ & Preschool & $\begin{array}{l}\text { Elementar } \\
\text { y }\end{array}$ & $\begin{array}{l}\text { Middle } \\
\text { School }\end{array}$ & $\begin{array}{l}\text { High } \\
\text { School }\end{array}$ & & & \\
\hline$n$ & 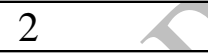 & 48 & 23 & 24 & & & \\
\hline $\begin{array}{l}\text { Official } \\
\text { Role }\end{array}$ & $\begin{array}{l}\text { Train G/T } \\
\text { professional } \\
\text { s }\end{array}$ & $\begin{array}{l}\text { School } \\
\text { Administr } \\
\text { ator }\end{array}$ & $\begin{array}{l}\text { Counselor } \\
\text { /Psycholo } \\
\text { gist }\end{array}$ & $\begin{array}{l}\mathrm{G} / \mathrm{T} \\
\text { Researche } \\
\mathrm{r}\end{array}$ & & & \\
\hline$n$ & 30 & 14 & 9 & 90 & & & \\
\hline Involvement & $\begin{array}{l}\text { Attend G/T } \\
\text { Meetings }\end{array}$ & $\begin{array}{l}\text { Received } \\
\text { G/T } \\
\text { Teaching } \\
\text { Certificati } \\
\text { on }\end{array}$ & $\begin{array}{l}\text { Encourage } \\
\text { G/T } \\
\text { Programm } \\
\text { ing }\end{array}$ & $\begin{array}{l}\text { Try to } \\
\text { Influence } \\
\text { G/T } \\
\text { Practice }\end{array}$ & $\begin{array}{l}\text { Trying to } \\
\text { Learn More } \\
\text { About G/T }\end{array}$ & & \\
\hline$n$ & 193 & 81 & 182 & 205 & 261 & & \\
\hline $\begin{array}{l}\text { Parent of } \\
\text { G/T child }\end{array}$ & Yes & No & & & & & \\
\hline$n$ & 249 & 89 & & & & & \\
\hline $\begin{array}{l}\text { Children } \\
\text { attended }\end{array}$ & $\begin{array}{l}\text { Public } \\
\text { Schools } \\
\end{array}$ & $\begin{array}{l}\text { Private } \\
\text { Schools }\end{array}$ & $\begin{array}{l}\text { Home } \\
\text { Schooled }\end{array}$ & & & & \\
\hline$n$ & 177 & 49 & 27 & & & & \\
\hline $\begin{array}{l}\text { "I am a } \\
\text { gifted }\end{array}$ & Yes & No & & & & & \\
\hline
\end{tabular}




\begin{tabular}{|l|l|l|l|l|l|l|l|}
\hline person." & & & & & & & \\
\hline$n$ & 253 & 82 & & & & & \\
\hline
\end{tabular}

Table 4. Response profile for latent classes on the classification variables

\begin{tabular}{lcc}
\hline Variable & $\begin{array}{c}\text { Individualists } \\
(n=109)\end{array}$ & $\begin{array}{c}\text { Communitarians } \\
(n=109)\end{array}$ \\
\hline BESTID & & \\
Test & $74.9 \%$ & $80.3 \%$ \\
Other method & $25.1 \%$ & $19.7 \%$ \\
COOPLRN & & \\
Often & $3.0 \%$ & $74.2 \%$ \\
Seldom & $80.4 \%$ & $25.8 \%$ \\
Never & $16.5 \%$ & $0 \%$ \\
COOPBEN & & \\
Academic & $0.7 \%$ & $6.5 \%$ \\
Social & $26.7 \%$ & $92.6 \%$ \\
None & $72.6 \%$ & $0.9 \%$ \\
BESTPGM & & $39.8 \%$ \\
Differentiated Curr & $7.5 \%$ & $18.7 \%$ \\
Pullout Programs & $1.3 \%$ & $19.5 \%$ \\
Cluster Groups & $17.9 \%$ & $11.6 \%$ \\
Self-Contained & $69.1 \%$ & $0.9 \%$ \\
Residential & $0.9 \%$ & $3.6 \%$ \\
Elite Private School & $0 \%$ & $5.9 \%$ \\
Home School & $3.3 \%$ & \\
& &
\end{tabular}


Table 5. Predicted group mean scores

\begin{tabular}{|r|c|c|}
\hline & $\begin{array}{c}\text { Group 1 } \\
(n=109)\end{array}$ & $\begin{array}{c}\text { Group 2 } \\
(n=109)\end{array}$ \\
\hline $\begin{array}{r}\text { SDO } \\
M(S D)\end{array}$ & $2.43(.84)$ & $2.44(.73)$ \\
\hline $\begin{array}{r}\text { RWA } \\
M(S D)\end{array}$ & $2.60(1.1)$ & $3.30(1.2)$ \\
\hline $\begin{array}{r}\text { MCS } \\
M(S D)\end{array}$ & $4.30(.67)$ & $4.26(.80)$ \\
\hline
\end{tabular}

Table 6. Slopes relating group membership with group membership, with Group 1 (Individualists) as reference.

\begin{tabular}{lr}
\hline Variable & Slope \\
\hline SDO & $0.723^{*}$ \\
MCS & 0.216 \\
RWA & $-0.834^{*}$ \\
\hline$* p<0.05$ &
\end{tabular}


Supporters of Gifted Education 43

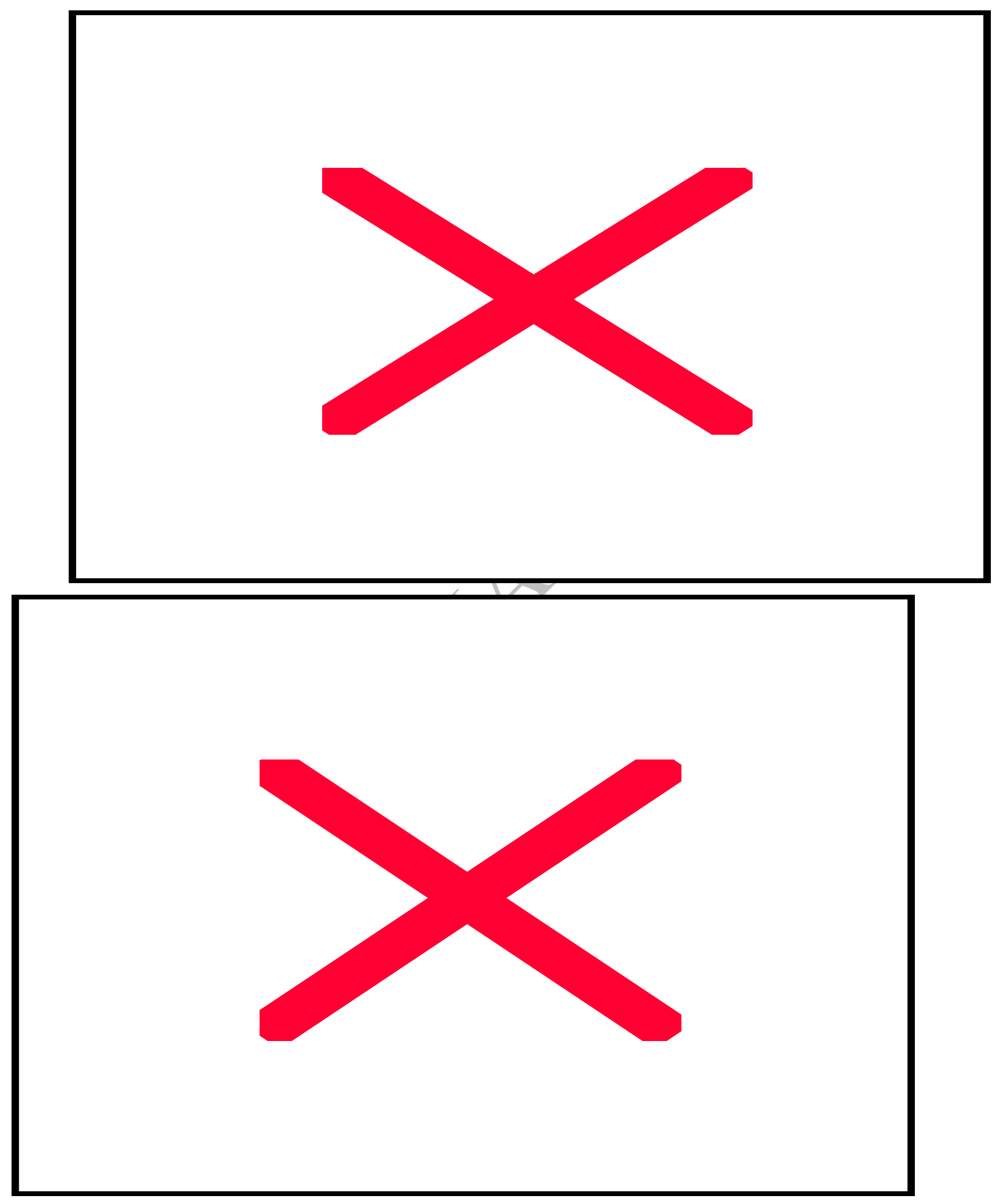


Supporters of Gifted Education 44

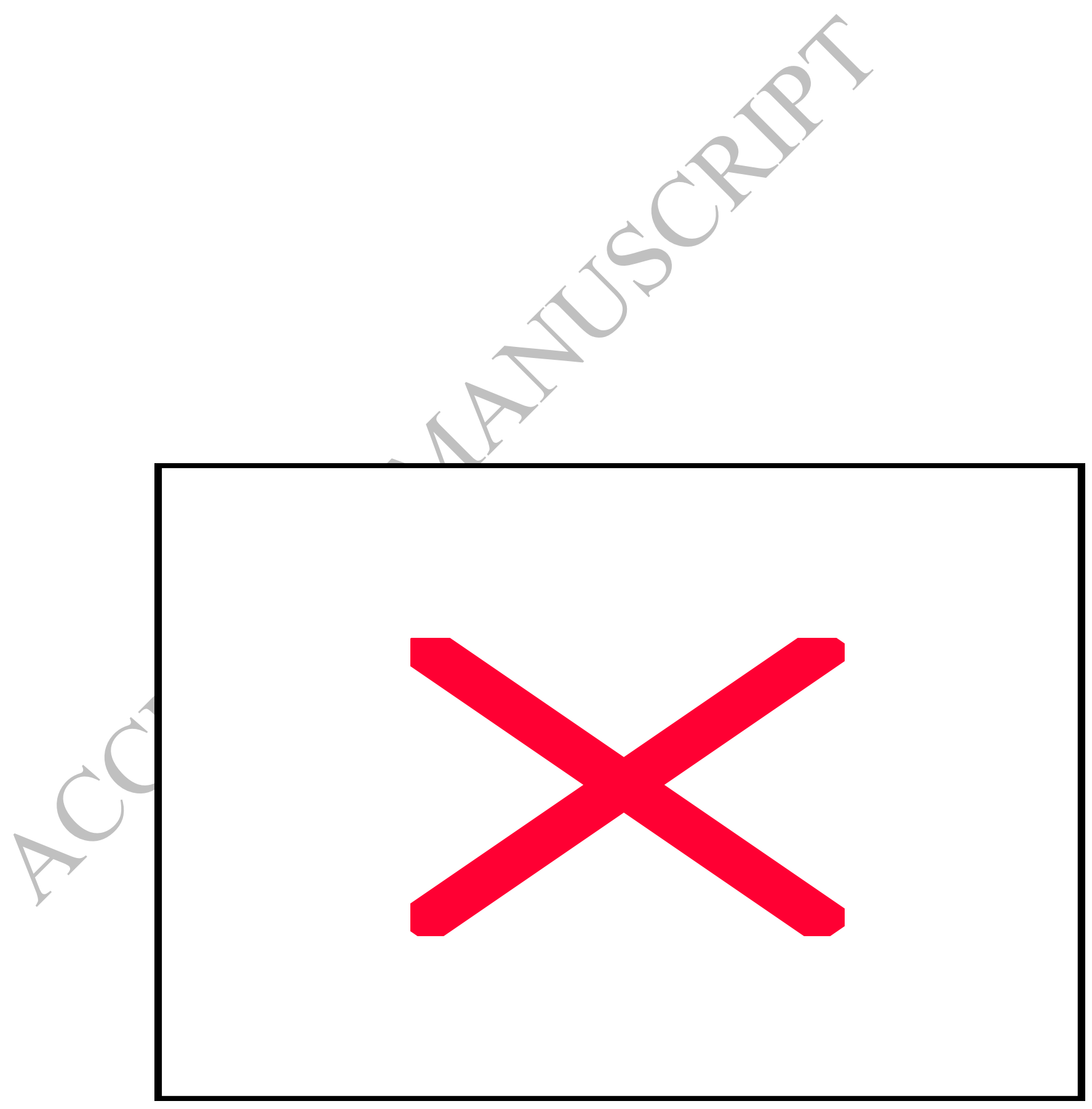




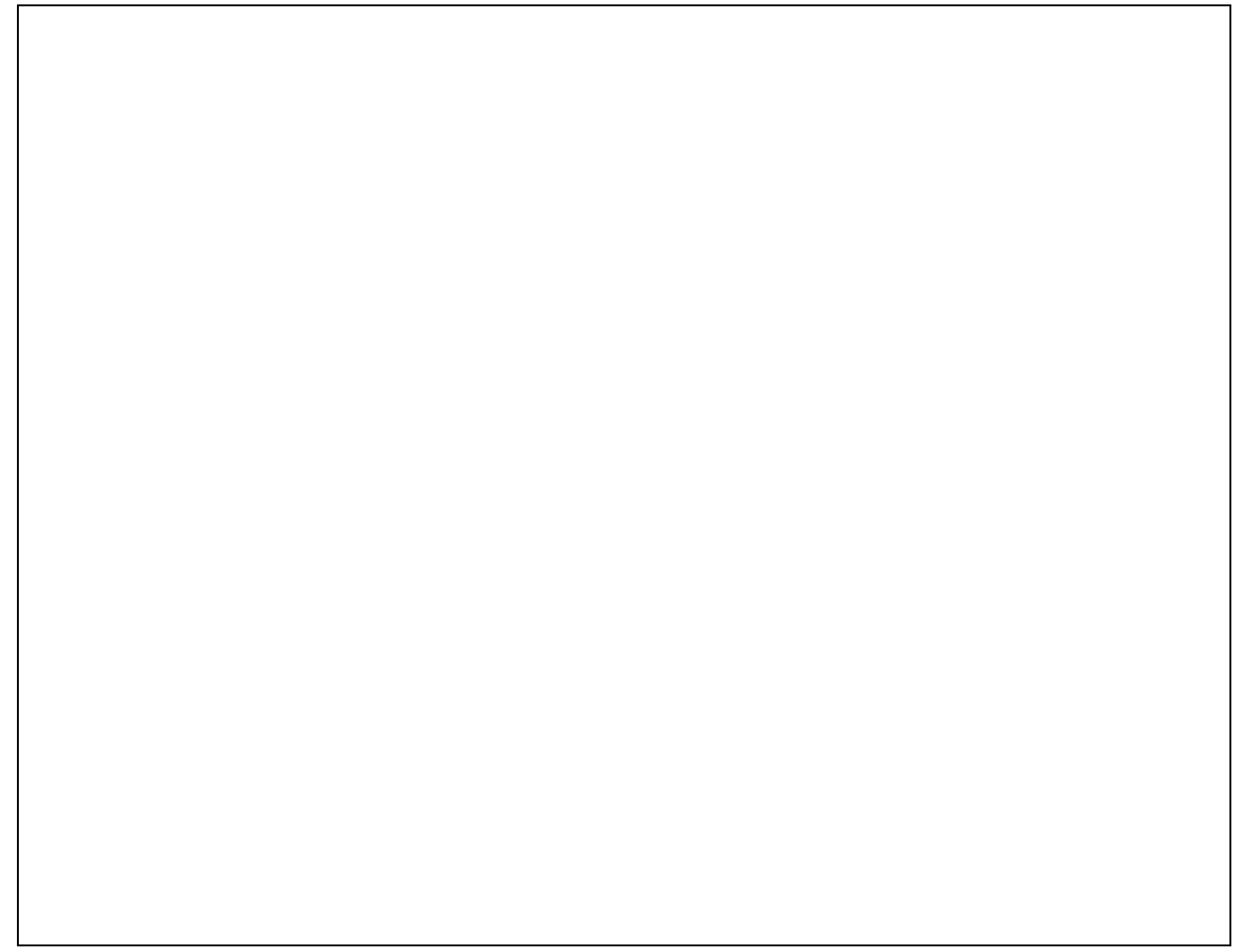

